\title{
Introducing Creativity In A Design Laboratory For A Freshman Level Electrical And Computer Engineering Course
}

Susan L. Burkett, The University of Alabama, USA Sushma Kotru, The University of Alabama, USA John C. Lusth, The University of Alabama, USA

Debra McCallum, The University of Alabama, USA Sarah Dunlap, The University of Alabama, USA

\begin{abstract}
In the electrical and computer engineering (ECE) curriculum at The University of Alabama, freshmen are introduced to fundamental electrical concepts and units, DC circuit analysis techniques, operational amplifiers, circuit simulation, design, and professional ethics. The two credit course has both lecture and laboratory components that address these topics. The laboratory has been used, in this project, to provide students an experience in design. In one of the laboratory assignments, students work in teams to design and build products giving attention to both function and aesthetics. Creativity is an important attribute for engineers practicing their profession in a global society. The creative process was exercised in the design lab by progressively engaging students through various stages including: brainstorming, formation of a construction plan, producing schematic representations, and implementing their design. In a twoyear period, four laboratory exercises were developed to provide design experiences in our introductory ECE course. Assessment results show that the majority of students enjoy several aspects of the laboratory on design and creativity. At the same time, they consider this lab to be one of the most difficult ones due to its open-ended nature. Students who experienced the creative lab were somewhat more likely to state they would continue in their major. Overall, the project team concluded that the creative lab was valuable and did raise awareness of the creative process.
\end{abstract}

Keywords: Creativity; Creative Process; Design; Laboratory

\section{INTRODUCTION}

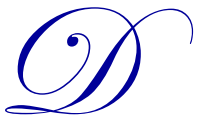

esign projects that lead to elegant and efficient solutions to engineering problems are an extremely important way to instill in students the need for brainstorming ideas, team work, and troubleshooting. Design has been given significant attention in science and engineering curricula. In most programs, design is dealt with at the upper level, typically in senior design projects, with some exceptions (Brandt, Fisher, Hansen, Kuennen, \& Neal, 2004; Grimheden, 2007; Hunter, 2004; Ohland, 2004; Warsame, Biney, $\&$ Morgan, 1995). Introductory courses tend to focus on teaching basic scientific principles and using systematic approaches to solve problems of interest to the discipline. An approach to problem solving that uses creativity by a student or team of students appears to be uncommon. However, most educators truly enjoy seeing a creative approach taken by their students in solving problems. We agree with Csikszentmihalyi that creativity has to spring from a solid foundation of knowledge. He describes creativity as the existence of rules in a symbolic domain involving experts that possess mastery of fundamental concepts that not only recognize changes in the domain but also appreciate the changes (Csikszentmihalyi, 1996). What is most often emphasized in open-ended problems, as 
part of course work, is proper operation or function of a product or system. Being creative throughout the process and paying attention to aesthetics of the final product or system tend to be de-emphasized. However, at least one group describes the use of notebooks to highlight creativity throughout the design process (Ekwaro-Osire, Mendias, \& Orono, 2009). Their motivation was to help distinguish individual creativity from creativity by the project team. Another group taught a multi-disciplinary course, including students from an interactive multimedia program, to focus on creating useful products with visual appeal (Salgian, Nakra, Ault, \& Wang, 2013). The intention in incorporating an element of creativity in the laboratories described in this paper was similar to the goals described in the work of Salgian et al.

As part of an NSF Course, Curriculum, and Laboratory Improvement (CCLI) funded project, our introductory electrical and computer engineering (ECE) course was modified to add a lab that emphasizes creativity. The goal of this project was to raise awareness of creativity in the design process and to think about problems in a non-formulaic manner. The advantage for a student in adopting this mode of thinking is that he or she gets practice in attacking problems in insightful ways. Several years ago, the ECE faculty at The University of Alabama (UA) created a two-credit course, Fundamentals of ECE, to introduce circuit analysis techniques to freshmen, given the fact that this skill is a fundamental one to master in ECE. The course has two fifty minute lectures per week. Like many introductory engineering courses, students are introduced to the profession with a variety of guest speakers, lectures on ethics and design, and exposure to computer simulation. In addition to the lecture component, five laboratories are required throughout the semester: soldering experience, analysis of an automobile lighting system, maximum power transfer, assembling simple operational amplifier circuits, and building a crystal radio set. The approach to each laboratory assignment is to provide students with step-by-step instructions. In the NSF project, the maximum power transfer lab was replaced with a lab that allowed for more student creativity. The CCLI project was titled, "When Art and Engineering Collide." As the project title suggests, the artistic component was given more attention than would be typical in an introductory course.

The average enrollment in this course was approximately 50 students per semester. Each semester over the two-year grant period, a different creative laboratory module was given. The four variations were: designing a lamp from a musical instrument, designing the housing for a low power computer, designing a solar powered wind chime, and designing housing for an AM radio. The creative laboratory was held over a three-week period, as compared to other laboratories that were completed in one or two weeks. The major components for each creative module were supplied to the students with small project budgets $(\$ 10-\$ 20)$ for any additional items. Students were encouraged to use recycled or repurposed materials. After the grant period ended, students taking the course without the creative lab served as a control group for assessing the lab's impact.

\section{BACKGROUND}

To compete globally, employers are expecting new hires, especially those possessing advanced degrees, to be innovative and possess entrepreneurial skills. Globalization is stressed as a critical issue for the success of future STEM professionals in both The Engineer of 2020 (National Academy of Engineering (NAE), 2004) and Educating the Engineer of 2020 documents (NAE, 2005). To be successful in science and engineering, a student's skill set should include autonomy, critical thinking, and creativity (Barron \& Harrington, 1981; Jonathan \& Franklin, 2009; Mackinnon, 1962). Creativity is considered a trait or attribute that can provide a competitive edge in globalization (Patton \& Bannerot, 2002), yet most technology-based curricula do not have courses that emphasize this skill. A disadvantage in emphasizing function over form is that little attention is given to visual considerations during the design process. Visual considerations are a dominant aspect in marketing products that have wide appeal. For technology-driven products with broad applications, design should include all relevant features: functionality, cost, aesthetics, safety, etc. Creativity and innovation allows one to minimize the tradeoffs between these disparate features.

Over a decade ago, the Accreditation Board for Engineering and Technology (ABET) revised the accreditation criteria for undergraduate degrees in engineering. Most of the revised program outcome assessments were based on the development of critical thinking skills (Ralston \& Bays, 2010). There are many ways to incorporate critical thinking into engineering classes, such as writing assignments, active learning strategies, and project-based design experiences. Creativity can be closely linked to critical thinking. Both are complex and multi- 
dimensional (Sternberg, 2005). The National Academies describe creativity as a high but attainable bar in engineering education (NAE, 2005) and one that should not be ignored given the technical challenges the world is facing. It makes sense that students be introduced to critical thinking and projects that involve creativity early in the curriculum so that they have time to fully develop those skills.

Generally, the undergraduate engineering curriculum is built around courses that develop skills in manipulation of equations based on foundational principles. Students are taught to attack problems by pattern matching. Interestingly, Genco, Holtta-Otto, \& Seepersad $(2010,2011)$ found designs generated by freshman engineering students to have a higher score in their rubric than designs generated by seniors and they believe this was due to an open-minded approach, not hampered by association with patterns that might be taken by novices. In another study, the choice of environment in which creativity is to take place had a profound effect on the success of the creative effort. Robertson, Walther, \& Radcliffe (2007) found that designing within the context of a CAD system led to a suppression of creative thought, primarily through the limitations of the CAD system itself and a tendency to fixate on details of early designs. While there is no doubt that pattern-matching skills are important, problem solving opportunities that allow students to exercise creativity are less common. Restrictions, such as requirements to fulfill ABET program assessments or maintaining a certain number of program course credits, make adding new courses to an undergraduate curriculum almost impractical, if not impossible. However, educators can take various approaches to give students an opportunity to exercise creativity. This can be done by integrating creativity in classroom activities (Hassan, 2004), using a technique based on the work of Keller (Keller, 1983) referred to as inquiry arousal (Miles \& Chewar, 2007), adding laboratories and capstone design experiences (Shields, 2007), assigning an innovative embedded systems project (Wilkinson, Miles, Bateson, Selke, \& Holley, 2002), developing an accompanying textbook for a course (Lumsdaine, Lumsdaine, \& Shelnutt, 1999) or offering a technical course to students with a background in the arts (Sundaram \& Ingalls, 2006). A summer program where students and faculty work with teenagers to create a "magic show" based on scientific principles is an example of a creative way to involve youth (Papalaskari et al., 2007). Project-based learning is another effective way to enable students to connect discipline specific topics to personal interests and contexts (Stolk \& Olin, 2009).

At one institution, students from structural engineering and architecture were brought together in a seminar course to foster innovation and creativity (MacNamara, Olsen, Steinberg, \& Clemence, 2010). Students from these disciplines would rarely have opportunities for cross-disciplinary interaction. This study showed a clear difference in the self-perceptions of students with architecture students perceived as having more confidence in their skills in almost every area compared to the engineering students. Gerhart and Carpenter (2012) describe a multi-institutional summer residential camp that leveraged regional themes including visits to museums and manufacturing facilities to provide students a unique exposure to creativity and innovation. In other work, a "hybrid learning" approach was used where engineering and liberal arts education students worked together. This approach was found to foster innovation in students by making them comfortable with different learning styles (Traver \& Klein, 2011). Another interesting project took place in a junior design course that combined a team of engineering, art, and marketing students to create ideas for consumer products with a focus on design within constraints, maintaining commercial viability (Manohar, Jones, \& Radermacher, 2007). In another institution, art students interacted with engineering students in a senior design course to enhance the creativity of the project (Pidaparti, 2004). Another example involved engineering, art, and architecture students solving a community lighting problem as part of a servicelearning project (Pines, Fuller, \& Hahn, 2005).

According to Stouffer, Russell, \& Olivia (2004), the creative process is considered a progression through four stages: 1) identifying a need, 2) investigation of that need (preparation, testing, analysis), 3) an articulation of a solution, and 4) a validation of the idea or solution (communicating, evaluation). A well-defined procedure for the creative process makes this seemingly strange process more familiar to students (Papalaskari et al., 2007). Many think of brainstorming as an initial stage in the creative process. This activity is very important in conducting research, yet few students, undergraduate or graduate, get a chance to participate in these activities. Brainstorming can be very effective although when performed in a group, team dynamics play an important role. An introductory engineering course used the Myers-Briggs personality indicator test to measure student personalities (Parsons \& Klukken, 1995); the test results were used for formation of project teams. Other researchers have assessed student thinking preferences with the Herrmann Brain Dominance Instrument. Their research project showed that many engineering students become more left-brain dominant (highly analytical, logical, structured) as they progress 
through their curriculum. Yet quadrant $\mathrm{C}$ thinkers, (empathetic, emotional, interpersonal) were found to be preferred by industry (Lumsdaine \& Lumsdaine, 1994). A freshman course and textbook (Lumsdaine, Lumsdaine, \& Shelnutt, 1999) were developed by this research team to train engineering students to think more creatively.

When documenting historical creative discoveries and inventions to gain insight into the nature of creativity, reflection is considered to serve as a catalyst for creativity (Ghosh, 2003; Ghosh, 2006). This is an interesting finding as many would agree that the most creative ideas progress over time once sufficient thought and modification has been given to them. A process termed the creative design process is considered by some to integrate the engineering design process and the creative process established from cognitive psychology (Howard, Culley, \& Dekoninck, 2008). Understanding the components of creative design is essential in assessment efforts. Although literature suggests that creativity is essential for innovation, assessment of creativity and innovation in students remains a challenge. In creativity workshops, through a mixture of experiential and cognitive techniques, a mean creativity index was shown to change from a number typical for engineering students to a number more characteristic of practicing architects (Wilde, 1993). Recent work by Ragusa (Ragusa, 2011) describes another creativity and innovation index where reliability and validity testing has been performed. This metric is being used in three engineering programs nationally to measure creativity. Other attempts have been made to measure creativity in students and in assessing creative instruments (Abedi, 2002; Khatena \& Khatena, 1999; Torrance, 1981).

\section{PROJECT IMPLEMENTATION}

\subsection{Motivation}

This project was motivated by a fund raising opportunity for an event sponsored by the UA Department of Fine Arts. Faculty in the music department asked ECE faculty if students could build lamps from retired musical instruments. The lamps would then be auctioned at an annual spring event, referred to as the "Arty Party." Each year, this event highlights the UA Fine and Performing Arts programs. The ECE faculty decided that freshmen in our Fundamentals of ECE course would build the lamps. In our lecture/laboratory course, students are introduced to fundamental electrical engineering principles, the basic design process, ethics, and the importance of professional societies. The two credit course consists of two fifty-minute lectures in addition to one two-hour laboratory per week. In lecture, circuit analysis techniques form the majority of the technical content since circuit analysis is such an important skill in an ECE curriculum. The laboratory component consists of five labs as discussed in the introduction. They are designed to reiterate fundamental principles as well as provide hands on experience to students in soldering, placement of components on an electronic board, and conducting electronic measurements. The students are given step-by-step instructions on how to conduct each laboratory while a graduate teaching assistant supervises their work and answers questions they have about laboratory procedures.

In Spring 2008, just over 40 students were enrolled in the introductory ECE course. The students were tasked with the lamp project at mid-semester with two laboratory sessions (four hours total) to complete it. Students had a strict deadline for ordering any necessary parts. Each team, composed of five to six students, had a budget of approximately $\$ 50$ to spend on parts or accessories. The instruments to be converted consisted of a saxophone, clarinet, bassoon, piccolo, trumpet, mellophone, and trombone. Musical instruments were assigned to student teams with first priority given to students who had actual experience playing that instrument. In this pilot lab, all student teams designed functional lamps using creative implementations. They gained experience in brainstorming, teamwork, documentation of product specifications, and following a basic design process. The students seemed to enjoy the process and ability to work on an open-ended problem. At the fund raising event, the lamps sold for an average of $\$ 500$ per lamp and were considered to be a big success. Details of this project were presented at ASEE in 2009 (Burkett \& Snead, 2009). This project inspired a proposal to the National Science Foundation (NSF). This paper describes the grant activity that resulted from the NSF grant.

\subsection{Logistics}

As part of the NSF grant, four laboratories were created and offered, beginning in Fall semester 2009 through Spring semester 2011. Students were surveyed each semester as part of the evaluation process. In the 
2011-2012 academic year, the laboratory in exercising creativity was not offered so that students could be surveyed and their responses compared to students who participated in the creative laboratories. The four laboratories included designing: a) a lamp from a musical instrument; b) a housing for the hardware of a low power computer that the students built; c) a solar powered wind chime; and d) a housing for an AM radio built from a kit. Each semester, the project team attempted to find a product that would appeal to students from a technical standpoint but also have an artistic component. For each laboratory product, it was necessary to provide some additional information about the components and/or design constraints. This could usually be done in the laboratory by the graduate teaching assistant before beginning the project or occasionally lecture time was devoted to this aspect so that it could be done just once rather than repeating for each section.

The typical class size grew $25 \%$ per semester during the grant period and for much of that time, the lecture portion was taught in two nearly equal sized sections. Labs met weekly over a two-hour period. Student teams were formed for the creative design lab with no more than four students in each team. Most laboratory assignments could be completed in two sessions. In the case of the creative design lab, three lab sessions were necessary to complete projects. For the creative lab, student teams were given a chance to brainstorm ideas and to formalize their designs in the first session. In the next session, they constructed sketches, documented and requested any parts or tools needed, and prepared a draft budget. In the third and final session, they finished implementation of their product. A lab report was due one week following the final session. At the end of each semester, a competition was held where student projects were judged on both function and appearance. Each event was widely advertised. Faculty, the Engineering Dean and Associate Deans, graduate students, Co-op and Career Center personnel, and Creative Campus staff and interns were invited to judge the competition. Students were welcome to invite their friends. It is perhaps noteworthy, that every semester, at least one student invited family members to attend the competition. Campus bookstore gift cards were given as prizes to the project that received the most votes in a variety of categories.

\subsection{Laboratory Modules}

This section describes each of four laboratories developed during the NSF CCLI grant period. A previous publication describes the first three laboratories briefly without specific attention to assessment (Burkett, Lusth, \& Kotru, 2011). In this paper, the lesson content and skills will be listed for each laboratory. Moreover, assessment of student interest in the creative labs will be described in a subsequent section. Each of the laboratories varies primarily by the end product. All of the labs emphasize brainstorming, team work, design, and building functional products.

\subsubsection{Lamps from Musical Instruments}

Lesson Content: Simple wiring, Design within a budget, Schematic production

Skills: Brainstorming, Team work, Parts acquisition, Integration of components

The purpose of this lab was to build a lamp from a musical instrument. Because this lab was also run as a pilot before acquiring NSF funding, this particular lab has been taught twice. In both cases, the UA music department provided the musical instruments. Interestingly, music and engineering have many parallels with both disciplines applying fundamental principles to create a product with definite goals in mind. Musicians apply fundamental principles to the precise arrangement of sounds for a functional product. So much so that Kaplan et al. describe relationships between ABET criteria and music (Kaplan, McGuire, \& Kaplan, 2004). Recognizing the fact that music generally resonates with students (creating music, listening to music, playing musical instruments), educators have used music to provide interesting projects in engineering and computer science courses (Kitto, 2007; Lusth, 2006; Lusth, 2008; Schwarzmeier, Jacobsen, Vang, \& Phillips, 2007) that increase students' enthusiasm for learning.

Previous to the first session, a general lecture on lamp wiring was presented, covering safety issues and the importance of electrical codes. We added this lecture when we observed, during the pilot project, students encountering problems such as an instrument resting on the electrical cord or interference between an audio 
amplifier and a touch sensitive switch. In the first lab session, students appointed a team leader to help moderate discussions, guide activities, and delegate the required work. In this session, they also inspected their instruments and were provided lamp wiring kits. Students brainstormed ideas as a team and documented this activity for their report. In the second lab session, they formalized a plan for design implementation and put one team member in charge of producing a schematic of their lamp. Students generated a list that included all parts and tools they would need before their next lab. The third session was held two weeks later to allow time for parts to arrive and, in that session, students finalized the construction of their lamp. Students were asked to name their lamp. Some example names include: Saxy Time, Ben Dellophone, Crimson Piccolo, Tuba Tantrum, Picasso's Clarinet, Music Illuminates the Globe, and Mellodramatic.

\subsubsection{Computer Housings}

Lesson Content: Computer subsystems, Low power computing, Design, Sustainability

Skills: Brainstorming, Team work, Acquisition of repurposed materials, Building an enclosure within operational parameters

In this lab, students were asked to name the parts of a computer; on the successful naming of a part, they were given that particular part. When students felt they had received all the parts, they were asked to assemble and power them up with no other instruction. When powering up failed for various reasons, they requested the additional parts they needed. Once operational, students measured the energy consumption of these low power computers and were given the task of determining how many hamburgers they would need to eat to generate enough power using a stationary bicycle and generator to keep the computer running for a day. Solving this task required significant amount of web research coupled with many assumptions. The creative design aspect of this laboratory was to build a decorative housing for the computer using recycled or recyclable materials. In the same approach as the lamp laboratory, students spent time brainstorming and documenting their ideas before proceeding on to the design and build stages. Each team had no more than three students each, resulting in 18 unique computers. For the end of semester competition, prize categories were expanded because the students were tasked with using recycled materials and awards were given in four areas: artistic appearance, reuse of materials, biodegradability, and best of show. Some highlights for housing materials included a toaster, a suitcase, sticks, a speaker, and a log house built from newspapers. The students were asked to name their computers and example names included: Speakuter, Zazu's House, Smart House, Granny Smith, and Toasty Computer.

\subsubsection{Wind Chimes}

Lesson Content: Solar energy, Small motors, Design, Sustainability

Skills: Brainstorming, Team work, Acquisition of repurposed materials, Integration of components

After conducting labs where electricity and computing were major themes, the project team designated the third creative lab module as one highlighting solar energy. In this lab, students were provided a solar powered yard light purchased at Home Depot and a small motor purchased from a hobbyist web site. Students were shown how to disconnect the solar cell from the light and tasked with building a solar-powered wind chime. They designed the actual chiming mechanism and implemented some type of switch. As with the computer housing lab, students incorporated recyclable or repurposed materials. Again, students went through the various stages of brainstorming and planning before implementing designs. At the end-of-semester competition, prizes were given in four areas: artistic appearance, acoustics, reuse of materials, and best of show. Example wind chime names include: Headless Horseman, Furin, Fork N Tubes, Shiny Fate, and Hells Bells.

\subsubsection{Radios}

Lesson Content: AM radio fundamentals, Soldering using a kit, Design, Sustainability

Skills: Brainstorming, Team work, Acquisition of repurposed materials, Building an enclosure within operational parameters 
Each semester, as part of the assessment efforts, students were asked to choose their favorite lab. While the creative lab rated high on the list, a lab where students built an AM radio from a kit was routinely rated as their favorite. Perhaps this was due to the fact that the creative lab demanded much more time of the students. The radio lab is the last in the sequence and one in which students can generally finish in a single lab session. The project team decided to make the radio the basis for the fourth creative lab. Like the computers, students were asked to design a housing for the radio. The sustainability theme was used again, although this time students could only use materials they had "found." In this way, students made creative use of existing materials, promoting sustainability. Miscellaneous materials for building the housing (glue, nails, screws, tape, etc.) were provided to the student teams. As with other labs, brainstorming, documenting, and planning were required before building. This lab also culminated in an art show and competition with three prize categories: artistic appearance, reuse of materials, and durability. Example radio names include: Old School Boombox, Millenium Falcon, Singing paint can, and C. B. radio (a Charlie Brown lunch pail).

A collage showing a sample of the products of this laboratory is shown in Figure 1.

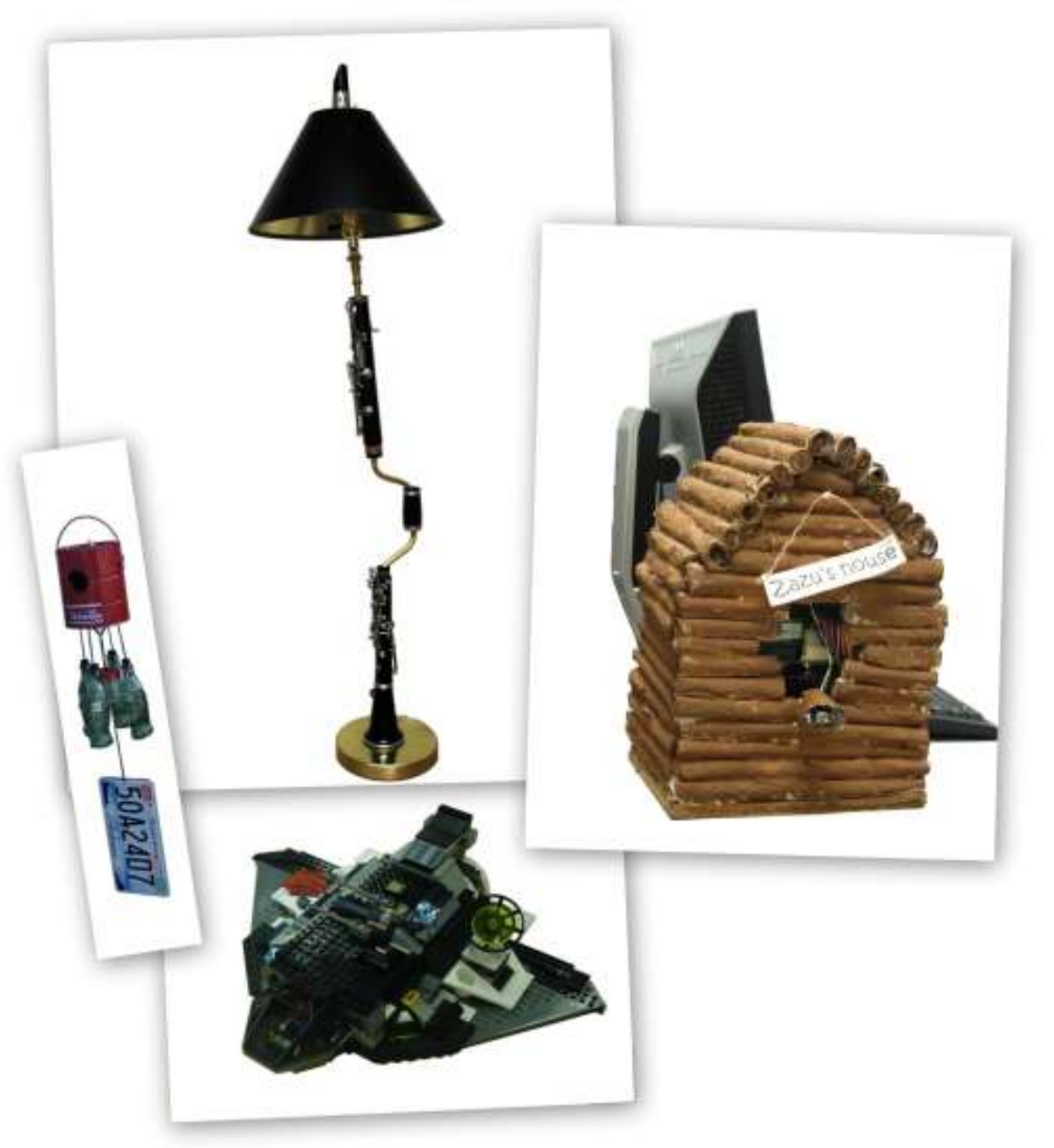

Figure 1: A Collage of Photographs Showing Example Products from the Creative Lab Project 


\section{EVALUATION}

Assessment efforts for this project were coordinated by personnel in the UA Institute for Social Science Research (ISSR). The evaluation tools were designed to assess the following three project objectives:

(1) Making ECE more appealing to students early in their academic career;

(2) Demonstrating that engineering is a creative process; and

(3) Prompting students to think about problems in a non-formulaic manner.

In addition, our project team looked at three additional questions:

(1) How is the creative lab perceived in comparison to the standard labs?

(2) How do the creative labs compare with each other?

(3) How were the semesters that included a creative lab viewed in comparison to a semester without such labs?

\subsection{Method}

These questions were addressed using three primary sources of data: student surveys, student outcomes, and feedback from the lab teaching assistants (TAs) and instructors.

Student surveys: A brief student survey was conducted following each of the lab exercises in the course (except for the first semester when all labs were rated at the end of the semester). These data were collected during the four semesters in the two year grant period in which students had one creative lab among the five labs scheduled for the course and in a control semester which contained no creative design lab. After the final lab of each semester, students completed an additional questionnaire asking about course related items with some comparative questions about the labs. The questionnaires were administered in written format by the evaluators. Questions were primarily close-ended rating scales and multiple-choice items, with several open-ended questions for follow-up and elaboration. All responses were anonymous.

Student performance (outcomes): Student outcomes in the form of data aggregated at the class level were obtained from the registrar's office and included course grades and enrollment in the next course in the series, as well as basic demographic information.

Instructor and teaching assistant feedback: Teaching assistants completed questionnaires and/or interviews regarding their perspective on the students' experiences with the creative labs and comparisons between the creative and standard labs. One TA was involved in both creative lab semesters and the control semester which had no creative lab to give a perspective for both situations. Instructors also provided feedback in the form of discussions that took place at the end of each semester when planning project activities for the subsequent semester.

\subsection{Results}

For the purposes of evaluation, the three stated objectives were assessed. Additionally, comparisons were made between the creative labs and the traditional labs, among the various forms of creative lab (lamps, computers, wind chimes, radios), and between the semesters with a creative lab and a control semester when the creative lab was not offered. We address the three objectives first and then turn to the broader comparisons.

\subsubsection{Objectives}

"When Art and Engineering Collide" began with three stated objectives. Specific items from the student surveys and instructor feedback were used to address these objectives.

Objective 1: To make the area of electrical and computer engineering (ECE) more appealing to students early in their academic career. Students who participated in the introductory ECE course in a semester where one of the laboratories included a creative component, were expected to demonstrate increased enthusiasm for 
the major. They were also expected to connect more strongly with faculty members in their department and with their classmates than students who were not involved in the creative design lab.

Students were asked at the conclusion of each semester how likely they were to continue majoring in engineering. Students completing the course during the semesters in which a creative lab was included rated themselves as somewhat more likely to continue majoring in engineering (mean $=4.75$ on a 5 -point scale) than students who completed the course without the inclusion of the creative lab (mean $=4.53$ ). While both means are quite high, this difference between the groups was marginally statistically significant $((F, 1,217)=3.295, p=.071)$, indicating a trend in the expected direction.

The instructors for the course reported greater interaction between themselves and the students during semesters in which the course included a creative lab. The students would often ask questions about "allowed" project materials or technical implementations with which they were having trouble. Additionally, students were very excited about displaying their products created during each creative lab at the end-of-semester "show case." This presentation to faculty, students, staff, and engineering administrators gave students an opportunity to interact with individuals with whom they might otherwise not have had the opportunity. Instructors reported that each semester, at least one student invited family members (parents, siblings, grandparents) to attend the project competition. The authors feel this says a lot about how students viewed this project and is consistent with previous results; in an introductory CS course where creativity was incorporated into the project, $64 \%$ of students indicated that they shared at least one program they created with a friend or family member (VanDeGrift, 2007). The display of ownership for their programs was considered a primary method for determining student enthusiasm in creative exercises. This same sense of pride was observed in our creative lab experiment.

Objective 2: Demonstrate to students that Engineering is a creative process. The expected outcome associated with this objective was that students participating in the creative labs would show increased awareness of the importance of skills that make up the creative process. However, results of the study showed no indication that students who participated in the creative design lab were more aware of the importance of creativity to engineering than those who did not. When asked how important they felt creativity was to the discipline of engineering, the mean responses were quite high, 4.41 on a 5-point scale for students who experienced the creative labs and 4.49 for those who completed only the standard labs. These means were not statistically different from each other. In addition, a sub-sample of participating students $(\mathrm{N}=119)$ who completed a brief $(10$-item) questionnaire designed to assess their attitudes revealed no differences between the two groups (with creative lab, mean $=3.48$; without creative lab, mean $=3.57$ on a 4-point scale; $t=1.46, p=.15$ ). These results seem to indicate that students, even early in their academic career, recognize the importance of creativity in engineering regardless of what type of activities they are engaging in through formal coursework.

Objective 3: Prompting students to think about problems in a non-formulaic manner. This objective had the expected outcome of having students demonstrate an approach to problem solving that is not captured by a single process, but involves a variety of methods to arrive at an answer. Instructors noted that students did display greater creativity during the designated "creative" labs. However, this tendency to demonstrate creative problem solving did not appear to transfer to later projects. Students did not appear to use their creative problem solving skills for subsequent assignments, perhaps due to the highly technical and structured nature of the remaining labs or perhaps due to a lack of complexity in troubleshooting the assignments.

\subsubsection{Comparisons across Labs and across Semesters}

Using ratings from the student surveys which were completed each semester, comparisons were made between the creative labs and the traditional labs, among the various creative labs themselves, and between the creative lab semesters and a control semester which had no creative lab.

\subsubsection{Comparing Creative Labs to Traditional Labs}

Means for the five creative labs collapsed across the four semesters in which they were offered are presented in Table 1. There are statistically significant differences among the labs for all variables. Lab 1 
(European siren) and Lab 5 (AM radio) were rated the highest in enjoyment and amount learned. Lab 3 (creative lab) was rated the highest in terms of need for brainstorming, problem-solving, and creativity. All labs received high ratings for sufficient resources and sufficient time for completion, but the creative lab was the one most likely to have some problems in this regard. Some early difficulties with access to supplies for the creative labs were resolved in later semesters, after which these particular ratings improved. All labs also received high ratings for how much students felt involved and how confident they felt about their performance. The highest ratings for involvement were for the European siren, Creative, and AM radio labs; and the highest ratings for confidence were for the European siren and AM radio labs. In these two labs, students worked independently to solder components together to create the end products. The project team expected this result because the students accomplish building these components independently, not as part of a team.

Table 1: Comparison of Creative Labs with Traditional Labs during the Grant Period (Fall 2009-Spring 2011).

\begin{tabular}{|c|c|c|c|c|c|c|c|}
\hline Questions asked following each lab: & $\begin{array}{c}\text { Lab } 1 \\
\text { Siren }\end{array}$ & $\begin{array}{c}\text { Lab 2 } \\
\text { Auto } \\
\text { lighting }\end{array}$ & $\begin{array}{l}\text { Lab 3 } \\
\text { Creative } \\
\quad \text { lab }\end{array}$ & $\begin{array}{c}\text { Lab 4 } \\
\text { OpAmp/ } \\
\text { O-scope }\end{array}$ & $\begin{array}{c}\text { Lab } 5 \\
\text { AM radio }\end{array}$ & $\begin{array}{c}\mathbf{F} \\
\text { value }\end{array}$ & $\underset{\text { level }}{p}$ \\
\hline $\begin{array}{l}\text { How much did you enjoy the lab? }(1= \\
\text { not at all; } 5=\text { very much })\end{array}$ & 4.29 & 3.50 & 3.91 & 3.69 & 4.41 & 41.85 & .000 \\
\hline $\begin{array}{l}\text { How much do you think you learned } \\
\text { from the lab? }(1=\text { very little; } 5=a \text { lot })\end{array}$ & 3.93 & 3.84 & 3.63 & 3.82 & 3.92 & 3.47 & .008 \\
\hline $\begin{array}{l}\text { To what extend did the lab require } \\
\text { brainstorming? }(1=\text { not at all; } 5=\text { very } \\
\text { much })\end{array}$ & 2.11 & 3.47 & 4.27 & 2.96 & 2.64 & 143.64 & .000 \\
\hline $\begin{array}{l}\text { To what extend did the lab require you } \\
\text { to used problem-solving skills? }(1= \\
\text { not at all; } 5=\text { very much })\end{array}$ & 2.30 & 3.53 & 3.96 & 2.96 & 2.77 & 88.92 & .000 \\
\hline $\begin{array}{l}\text { To what extent did the lab require you } \\
\text { to be creative? }(1=\text { not at all; } 5=\text { very } \\
\text { much })\end{array}$ & 1.85 & 2.20 & 4.23 & 2.18 & 2.26 & 201.14 & .000 \\
\hline $\begin{array}{l}\text { Were there sufficient laboratory } \\
\text { resources for the tasks give to you? ( } \% \\
\text { yes) }\end{array}$ & $98 \%$ & $97 \%$ & $92 \%$ & $98 \%$ & $100 \%$ & 6.70 & .000 \\
\hline $\begin{array}{l}\text { Was there sufficient time allowed for } \\
\text { the tasks given to you? (\% yes) }\end{array}$ & $100 \%$ & $98 \%$ & $94 \%$ & $100 \%$ & $99 \%$ & 6.53 & .007 \\
\hline $\begin{array}{l}\text { How involved do you feel you were in } \\
\text { the activities required for this lab? }(1= \\
\text { very little; } 5=\text { a lot })\end{array}$ & 4.54 & 4.36 & 4.43 & 4.23 & 4.71 & 11.59 & .000 \\
\hline $\begin{array}{l}\text { How confident do you feel about your } \\
\text { performance on the activities require } \\
\text { for this lab? }(1=\text { very little; } 5=\mathrm{a} \text { lot })\end{array}$ & 4.70 & 4.35 & 4.45 & 4.40 & 4.72 & 12.80 & .000 \\
\hline $\begin{array}{l}\text { How helpful was your mentor during } \\
\text { this laboratory exercise? }(1=\text { not at all; } \\
5=\text { very much })\end{array}$ & N/A & N/A & 4.43 & N/A & N/A & & \\
\hline $\begin{array}{l}\text { Compared to other group members } \\
\text { how much did you contribute to the } \\
\text { overall lab exercise? }(1=\text { contributed } \\
\text { the least; } 5=\text { contributed the most })\end{array}$ & N/A & N/A & 3.81 & N/A & N/A & & \\
\hline
\end{tabular}

When students were asked at the end of the semester to compare all labs (see Table 2), the creative lab (Lab 3 ) was most often selected as the most difficult lab (50.4\%); and it was also selected, along with the AM radio lab $($ Lab 5) as the most enjoyable lab (creative $=39.7 \%$; AM radio $=40.8 \%$ ). 
Table 2: Student Comparisons of Five Labs Completed during the Semester

\begin{tabular}{|c|c|c|c|c|c|}
\hline Questions asked at the end of the semester: & $\begin{array}{c}\text { Lab 1 } \\
\text { European } \\
\text { siren } \\
\end{array}$ & $\begin{array}{c}\text { Lab } 2 \\
\text { Auto lighting } \\
\text { system }\end{array}$ & $\begin{array}{c}\text { Lab 3 } \\
\text { Creative } \\
\text { lab } \\
\end{array}$ & $\begin{array}{c}\text { Lab 4 } \\
\text { Amplifier/ } \\
\text { oscilloscope }\end{array}$ & $\begin{array}{c}\text { Lab 5 } \\
\text { AM } \\
\text { radio }\end{array}$ \\
\hline $\begin{array}{l}\text { Which laboratory exercise did you find the most } \\
\text { enjoyable? }\end{array}$ & $5.0 \%$ & $5.0 \%$ & $39.7 \%$ & $9.5 \%$ & $40.8 \%$ \\
\hline $\begin{array}{l}\text { Which laboratory exercise did you find the least } \\
\text { enjoyable? }\end{array}$ & $7.3 \%$ & $41.9 \%$ & $20.7 \%$ & $28.5 \%$ & $1.7 \%$ \\
\hline $\begin{array}{l}\text { Which laboratory exercise did you find the most } \\
\text { difficult? }\end{array}$ & $3.1 \%$ & $28.2 \%$ & $50.4 \%$ & $6.1 \%$ & $12.2 \%$ \\
\hline Which laboratory exercise did you find the easiest? & $45.0 \%$ & $10.9 \%$ & $3.9 \%$ & $32.6 \%$ & $7.8 \%$ \\
\hline
\end{tabular}

\subsubsection{Comparing the Four Creative Labs to Each Other}

Results for comparisons among the four creative labs are presented in Table 3. Student ratings of the four creative labs, one in each semester, were comparable in terms of enjoyment, learning, involvement, and contributions. The musical instrument lamps lab received the highest ratings for requiring problem-solving, while ratings for the computer housing lab were the lowest on brainstorming, problem-solving, creativity, and students' confidence in their performance. In the lamp lab, which took place in the first semester of the project, students were least satisfied with the availability of resources and this problem was corrected for the remaining semesters.

Table 3: Comparison of Different Creative Labs across Semesters

\begin{tabular}{|c|c|c|c|c|c|c|}
\hline \multirow[b]{2}{*}{ Question } & \multicolumn{4}{|c|}{ Semester and Lab } & \multicolumn{2}{|c|}{$\begin{array}{l}\text { One-way ANOVA } \\
\text { comparing means }\end{array}$} \\
\hline & $\begin{array}{c}\text { F2009 } \\
\text { Musical } \\
\text { instrument lamps }\end{array}$ & $\begin{array}{c}\text { S2010 } \\
\text { Computer } \\
\text { housing }\end{array}$ & $\begin{array}{c}\text { F2010 } \\
\text { Solar-powered } \\
\text { wind chimes }\end{array}$ & $\begin{array}{c}\text { S2011 } \\
\text { AM radio } \\
\text { housing }\end{array}$ & $\begin{array}{c}\text { F value } \\
(\mathbf{d f}= \\
\mathbf{3 , 1 9 4})\end{array}$ & $\begin{array}{c}\text { p level } \\
(\text { ns = not } \\
\text { significant) }\end{array}$ \\
\hline $\begin{array}{l}\text { How much did you enjoy the lab? } \\
(1=\text { not at all; } 5=\text { very much })\end{array}$ & 3.92 & 3.88 & 4.14 & 4.04 & .683 & ns \\
\hline $\begin{array}{l}\text { How much do you think you } \\
\text { learned from the lab? }(1=\text { very } \\
\text { little; } 5=\mathrm{a} \text { lot })\end{array}$ & 3.73 & 3.41 & 3.65 & 3.66 & .690 & ns \\
\hline $\begin{array}{l}\text { To what extent did the lab require } \\
\text { brainstorming? }(1=\text { not at all; } 5= \\
\text { very much })\end{array}$ & 4.49 & 4.21 & 4.47 & 4.66 & 2.36 & .073 \\
\hline $\begin{array}{l}\text { To what extent did the lab require } \\
\text { you to use problem-solving skills? } \\
(1=\text { not at all; } 5=\text { very much })\end{array}$ & 4.59 & 3.48 & 4.22 & 4.07 & 9.35 & .000 \\
\hline $\begin{array}{l}\text { To what extent did the lab require } \\
\text { you to be creative? }(1=\text { not at all; } \\
5=\text { very much) }\end{array}$ & 4.76 & 4.29 & 4.73 & 4.63 & 4.40 & .005 \\
\hline $\begin{array}{l}\text { Were there sufficient laboratory } \\
\text { resources for the tasks given to } \\
\text { you? ( } \% \text { yes) }\end{array}$ & $78 \%$ & $95 \%$ & $90 \%$ & $95 \%$ & 3.04 & .030 \\
\hline $\begin{array}{l}\text { Was there sufficient time allowed } \\
\text { for the tasks given to you? ( } \% \text { yes) }\end{array}$ & $89 \%$ & $93 \%$ & $96 \%$ & $93 \%$ & .510 & ns \\
\hline $\begin{array}{l}\text { How involved do you feel you } \\
\text { were in the activities required for } \\
\text { this lab? }(1=\text { very little; } 5=a \text { lot })\end{array}$ & 4.46 & 4.38 & 4.59 & 4.58 & 1.087 & ns \\
\hline $\begin{array}{l}\text { How confident do you feel about } \\
\text { your performance on the activities } \\
\text { required for this lab? }(1=\text { very } \\
\text { little; } 5=\text { a lot) }\end{array}$ & 4.59 & 4.20 & 4.63 & 4.29 & 3.88 & .010 \\
\hline $\begin{array}{l}\text { How helpful was your TA during } \\
\text { this laboratory exercise? }(1=\text { not } \\
\text { at all; } 5=\text { very much })\end{array}$ & 4.38 & 4.30 & 4.51 & 4.52 & .964 & ns \\
\hline $\begin{array}{l}\text { Compared to other group members } \\
\text { how much did you contribute to } \\
\text { the overall lab exercise? (1 = } \\
\text { contributed the least; } 5= \\
\text { contributed the most) }\end{array}$ & 3.88 & 3.82 & 3.84 & 3.75 & .250 & ns \\
\hline
\end{tabular}




\subsubsection{Comparing Grant Period Semesters to a Standard Semester}

The third comparison conducted using student ratings was between the semesters in which there was a creative lab and a control semester. The results of this analysis are presented in Table 4. This analysis, based on ratings from the questions about the overall course, revealed two marginally significant differences. Students in the control semester gave somewhat higher ratings to the amount they learned from the labs in the course; and students in the creative lab semesters gave somewhat higher ratings to their likelihood of continuing to major in engineering.

Table 4: Mean Overall Ratings Comparing Four Creative Lab Semesters with One Control Semester

\begin{tabular}{|c|c|c|c|}
\hline Question & $\begin{array}{c}\text { Total over } 4 \text { creative } \\
\text { lab semesters } \\
(\text { F2009-S2011) } \\
(\mathbf{N}=\mathbf{1 8 0})\end{array}$ & $\begin{array}{c}\text { F2011 } \\
\text { Control } \\
(\mathbf{N}=41)\end{array}$ & $\begin{array}{c}\text { Test of comparison } \\
\text { between total } \\
\text { creative lab and } \\
\text { control } \\
\end{array}$ \\
\hline $\begin{array}{l}\text { How much did you enjoy the labs you completed in } \\
\text { this course? }(1=\text { not at all; } 5=\text { very much })\end{array}$ & 4.19 & 4.20 & ns \\
\hline $\begin{array}{l}\text { How much do you think you learned from the labs } \\
\text { completed in this course? }(1=\text { very little; } 5=\mathrm{a} \text { lot })\end{array}$ & 4.13 & 4.39 & $\begin{array}{c}F(1,220)=2.99 \\
p=.085\end{array}$ \\
\hline $\begin{array}{l}\text { How helpful was the TA for this course during } \\
\text { laboratory exercises? }(1=\text { not at all; } 5=\text { very much })\end{array}$ & 4.78 & 4.78 & ns \\
\hline $\begin{array}{l}\text { How much do you feel this course has contributed to } \\
\text { your engineering background? }(1=\text { not at all; } 5= \\
\text { very much) }\end{array}$ & 4.23 & 4.39 & ns \\
\hline $\begin{array}{l}\text { How important do you feel creativity is to the } \\
\text { discipline of engineering? ( } 1=\text { not at all; } 5=\text { very } \\
\text { much) }\end{array}$ & 4.41 & 4.49 & ns \\
\hline $\begin{array}{l}\text { Have you shared anything that you have learned in } \\
\text { this course with friends or family members? ( } \% \text { yes) }\end{array}$ & $71 \%$ & $73 \%$ & ns \\
\hline $\begin{array}{l}\text { How likely are you to continue majoring in } \\
\text { engineering? }(1=\text { not at all likely; } 5=\text { very likely })\end{array}$ & 4.75 & 4.53 & $\begin{array}{c}F(1,217)=3.29 \\
p=.071\end{array}$ \\
\hline
\end{tabular}

ns $=$ not significant

\subsubsection{Instructor Comments}

Instructors, including teaching assistants, who were involved in incorporating the creative labs into the introductory course noted that the opportunity for students to exercise their creative skills and be involved in the design aspect of engineering was a novelty which allowed them to build confidence in their skills and practice brainstorming and thinking creatively. They noted that the creative labs, while not touching as much on the principles learned during the course as some of the other labs, gave the students a chance to learn "differently." The hands-on aspect of these labs made it more applicable to "real-world" experiences, in contrast to the other labs. More critical thinking was required by the creative labs and those labs provided an opportunity for students to work in teams. Students appeared to enjoy the team work aspect. In addition, the instructors noted that students seemed more comfortable interacting with each other and with the instructors after completion of the creative labs. Specifically, participating in the course when creative labs were offered appeared to have an "ice breaker" effect. This effect seemed to be due to the less formal nature of working collaboratively toward a "creative" goal.

\subsubsection{Performance and Diversity}

In addition to the comparison of student ratings of the labs and an evaluation of the three project objectives, we looked at overall performance in the course (Table 5) to investigate any impact of the creative lab on student grades. Using institutional data aggregated at the course level, the four semesters before the creative labs began (Fall 2007-Spring 2009) were compared with the four semesters in which there was a creative lab (Fall 2009-Spring 2011). There are substantial semester-to-semester fluctuations in course grades, percentage of students passing, and percentages of female and minority students enrolled in the introductory ECE course making it difficult to see a clear pattern over time. However, combining across the four semesters before the creative labs began and the four semesters in which there was a creative lab, there is a significant trend toward slightly lower grades $(t=1.73, p<$ $.05)$ and a marginally significant trend toward lower pass rates $\left(X^{2}=3.64, p=.056\right)$ for the semesters incorporating a 
creative lab. Considering the creative lab is just one small aspect of the entire introductory course, the trend observed during this study is not believed to be related to incorporating the creative lab. As the university enrollment has dramatically increased in the past few years, more students are being recruited into engineering. The average ACT score of incoming students has been increasing over the years so one would not expect this trend unless more students are choosing electrical engineering without being prepared or truly motivated to study electrical engineering. Diversity in the course was also compared for these time periods. There is no difference in gender, but there is a somewhat higher, though not statistically significant, percentage of African American students for the semesters with the creative labs $\left(X^{2}=1.77, p=.19\right)$. Analyses of student ratings of the course by gender and by race revealed no significant differences or trends.

Table 5: Course Grades and Diversity

\begin{tabular}{|l|c|c|}
\hline & $\begin{array}{c}\text { 4 Semesters Before Creative } \\
\text { Labs }(\mathbf{N}=\mathbf{1 6 8})\end{array}$ & $\begin{array}{c}\text { 4 Semesters Using } \\
\text { Creative Labs }(\mathbf{N}=\mathbf{2 0 6})\end{array}$ \\
\hline Mean Course Grade $(\mathrm{A}=4, \mathrm{~B}=3, \mathrm{C}=2, \mathrm{D}=1, \mathrm{~F}=0)$ & 3.02 & 2.82 \\
\hline Percentage of students passing course with grade of C or higher & 88.69 & 81.55 \\
\hline Percentage female students in course & 13.69 & 14.56 \\
\hline Percentage African American students in course & 12.50 & 17.48 \\
\hline
\end{tabular}

\section{SUSTAINABILITY}

While the creative labs appear to provide some benefit, concerns arise as to how sustainable is the effort to offer these labs semester after semester. Three specific concerns are scalability, cost, and keeping the labs fresh. The use of a competition to inspire students allows for a large number of small teams. This is especially true if the competition can incorporate a head-to-head aspect with the winner advancing to the next round. Even teams that lose early can cheer on their friends or favorite entries in subsequent rounds. In terms of per-student cost, expenses can be kept low by relying on reusable components (e.g., the radio and computer housing labs), donated supplies (e.g., the musical lamps lab), and recycled and repurposed materials (e.g., the computer, wind chimes, and radio labs).

Finally, keeping labs fresh is an intellectual challenge. One possibility for simplification is to keep the same core purpose of the lab but varying constraints that must be met each semester. For example, in the housing labs, one semester might require that the housing must be disassembled and reassembled within a certain time period; the next might require the housing to weigh less than a specified amount yet withstand a specified amount of stress.

\section{SUMMARY}

In summary, a project involving creative design aspects was incorporated in a freshmen electrical and computer engineering course. Attention was given to progressing through a design in systematic stages as well to the artistic component of product design. Creativity is important for the future science and engineering workforce in terms of maintaining national competitiveness. Four different laboratories have been described for this purpose. Assessment of the laboratory portion of this course was done using student surveys and institutional data. Students generally rate all of the laboratories highly with the most enjoyable labs being the kit-based projects that involve soldering components together to make a working device. The creative labs are perceived by students as difficult, but also enjoyable. While they enjoy the creative lab, the fact that the project is open-ended and requires an intensive process to implement their design means that the lab is more time consuming and simply different than the other more formulaic labs. Creative labs were rated higher than other labs in terms of requiring creativity, problem solving, and brainstorming, something that one would expect to find. This fact makes it difficult to compare the labs. Students who experienced the creative lab were somewhat more likely to rate themselves as likely to continue majoring in engineering. Overall, the project team feels the experience is valuable for the students and that awareness of creativity is raised. One lab in a two-credit course does not change the students' ideas about the importance of creativity in engineering or their overall attitudes toward the course as it comprises only one minor aspect set in a larger framework. 


\section{ACKNOWLEDGEMENTS}

The authors acknowledge funding by the National Science Foundation CCLI program (now TUES), grant number DUE-0837226. The authors would like to thank The University of Alabama music department for donating musical instruments and UA Creative Campus staff for participating in brainstorming sessions to generate ideas for laboratory modules.

\section{AUTHOR INFORMATION}

Susan Burkett is the Alabama Power Foundation Endowed Professor in Electrical and Computer Engineering at The University of Alabama. She received her B.S., M.S., and Ph.D. degrees in Electrical Engineering from the University of Missouri in Columbia, Missouri. She teaches courses in circuit analysis, integrated circuit fabrication, and senior design. She served as Program Director at the National Science Foundation (NSF) in the Division of Undergraduate (DUE) Education from 2005-2007. Professor Burkett is a member of ASEE, AVS: Science and Technology Society, and a senior member of IEEE. E-mail: sburkett@eng.ua.edu (Corresponding author)

Sushma Kotru is an Associate Professor in electrical and computer engineering at The University of Alabama. She received her B.S. and M.S. degrees in Physics from the University of Kashmir. She earned M.Phil and Ph.D. degrees in Physics from the University of Jammu, India. Professor Kotru teaches courses in circuit analysis, thin film technology, and senior design. She is a member of AVS, MRS, WEE, IEEE UFFC, and a senior member of IEEE. She has authored or co-authored 56 referred papers and her research has been funded by DOD, NSF, ARO, NASA, and FAA. E-mail: skotru@eng.ua.edu

John Lusth is an Associate Professor of Computer Science and the Director of the First Year in Computing at The University of Alabama. He received his B.S. in Chemistry at Michigan Technological University, a M.S. in Computer Science at Duke University, and a Ph.D. in Computer Science at The University of Alabama. He teaches the introductory Computer Science course as well as Programming Languages and Computer-Assisted Music Composition and Generation. E-mail: $\underline{\text { lusth@cs.ua.edu }}$

Debra M. McCallum is a Senior Research Social Scientist and Director of the Institute for Social Science Research at The University of Alabama. She received her B.S. in Psychology from Furman University and her M.S. and Ph.D. degrees in Psychology from the University of North Carolina at Chapel Hill. She is a social psychologist interested in evaluations of education and community intervention programs and research concerning career choices as related to STEM, social-psychological aspects of health behavior and outcomes, and safety and well-being of children and youth. E-mail: dmccallu@ua.edu

Sarah Dunlap is a research associate at the Institute for Social Science Research at the University of Alabama. She received her B.S. in Psychology and her M.A. in Cognitive Psychology from the University of Alabama as well. She divides her time between project coordination and project evaluation for grant funded research. She is a member of AEA (American Evaluation Association) and SPSP (Society of Personality and Social Psychology). E-mail: $\underline{\text { sarahd@bama.ua.edu }}$

\section{REFERENCES}

1. Abedi, J. (2002). A latent-variable modeling approach to assessing reliability and validity of a creativity instrument. Creativity Research Journal, 14(2), 267-276.

2. Barron, F., \& Harrington, D. (1981). Creativity, intelligence, and personality. Annual Review of Psychology, 32, 439-476.

3. Brandt, S. A., Fisher, C. A., Hansen, D. S., Kuennen, S. T., \& Neal, P. J. (2004). Get 'EM while they're young! Integrated engineering for freshmen. Proceedings of the Annual ASEE Conference, 6125-6135.

4. Burkett, S. L., Lusth, J. C., \& Kotru, S. (2011). Creativity in an introductory engineering course. Proceedings of the Annual ASEE Conference. Annual ASEE Conference, Austin, TX. 
6. Csikszentmihalyi, M. (1996). Creativity: Flow and the psychology of discovery and invention.

HarperCollins Publishers.

7. Ekwaro-Osire, S., Mendias III, J. J., \& Orono, P. (2009). Using design notebooks to map creativity during team activities. Proceedings of the Frontiers in Education (FIE) Conference.

8. Genco, N., Holtta-Otto, K., \& Seepersad, C. C. (2010). An experimental investigation of the innovation capabilities of engineering students. Proceedings of the Annual ASEE Conference, Louisville, KY.

9. Genco, N., Holtta-Otto, K., \& Seepersad, C. C. (2011). Factors that influence the creativity of engineering students. Proceedings of the Annual ASEE Conference.

10. Gerhart, A. L., \& Carpenter, D. D. (2012). Creativity, innovation, and ingenuity summer enrichment program: Assessment from a multi-institutional collaboration. Proceedings of the Annual ASEE Conference.

11. Ghosh, S. (2003). Triggering creativity in science and engineering: Reflection as a catalyst. Journal of Intelligent and Robotic Systems: Theory and Applications, 38(3-4), 255-275.

12. Ghosh, S. (2006). The source and seat of creativity in human beings: A position paper. Proceedings of the $18^{\text {th }}$ IEEE International Conference on Tools with Artificial Intelligence (ICTAI), 261-264.

13. Grimheden, M. (2007). From Capstone courses to Cornerstone projects: Transferring experience from design engineering final year students to first year students. Proceedings of the Annual ASEE Conference.

14. Hassan, H. (2004). Creativity and innovation for electrical and computer engineering research. Proceedings of the Annual ASEE Conference.

15. Howard, T. J., Culley, S. J., \& Dekoninck, E. (2008). Describing the creative design process by the integration of engineering design and cognitive psychology literature. Design Studies, 29(2), 160-180.

16. Hunter Sr., K. W. (2004). A multidisciplinary team design project for first-semester engineering students and its implementation in a large introduction to engineering course. Proceedings of the Annual ASEE Conference, 10135-10139.

17. Jonathan, S., Franklin, W. O. (2009). Nurturing creative processes and attitudes in introductory materials science. Proceedings of the Annual ASEE Conference.

18. Kaplan, K. M., McGuire, J. A., \& Kaplan, J. J. (2004). The music of engineering. Proceedings of the Annual ASEE Conference, 10155-10168.

19. Khatena, J., \& Khatena, N. (1999). Developing creative talent in art: A guide for parents and teachers. Stamford, CT: Ablex Publishing.

20. Kitto, K. (2007). The sound of materials: Creating excitement for materials engineering and science in engineering technology programs. Proceedings of the Annual ASEE Conference.

21. Lumsdaine, E., \& Lumsdaine, M. (1994). Creative problem solving. IEEE Potentials, 13(5), 4-9.

22. Lumsdaine, E., Lumsdaine, M., \& Shelnutt, J. W. (1999). Creative problem solving and engineering design. McGraw-Hill.

23. Lusth, J. (2006). Connecting students to programming projects: Audio-based projects for data structures. Proceedings of the Annual ASEE Conference.

24. Lusth, J. (2008). Songlib: A library for music programming across the computer science curriculum. Proceedings of the Annual ASEE Conference.

25. Mackinnon, D. W. (1962). The nature and nurture of creative talent. American Psychologist, 17(7), 484495.

26. MacNamara, S., Olsen, C., Steinberg, L., \& Clemence, S. (2010). Inspiring innovation. Proceedings of the Annual ASEE Conference.

27. Manohar, P., Jones, C., \& Radermacher, J. (2007). Development and implementation of a junior-year design course in a multidisciplinary environment along with media art and marketing. Proceedings of the Annual ASEE Conference.

28. Miles, M., \& Chewar, C. M. (2007). Motivating with inquiry arousal: Creative problem solving in engineering courses. Proceedings of the Annual ASEE Conference.

29. National Academy of Engineering. (2004). Engineer of 2020: Visions of engineering in the new century. Washington, DC: National Academies Press.

30. National Academy of Engineering. (2005). Educating the engineer of 2020: Adapting engineering education to the new century. Washington, DC: National Academies Press.

31. Ohland, M. W. (2004). Clemson-FujiFilm partnership for introducing design to freshmen. Proceedings of the Annual ASEE Conference, 1905-1909. 
32. Papalaskari, M. A., Hess, K., Lagalante, A., Nadi, N., Styer, R., Way, T., \& Weinstein, R. (2007). Work in progress - Engineering the magic school creativity and innovation in context. Proceedings of the $37^{\text {th }}$ ASEE/IEEE Frontiers in Education (FIE) Conference, S2B-1-S2B-2.

33. Parsons, J. R., \& Klukken, P. G. (1995). An introductory design and innovation course at the University of Tennessee. Proceedings of the $25^{\text {th }}$ ASEE/IEEE Frontiers in Education (FIE) Conf., 3a5.13- 3a5.15.

34. Patton, A. H., \& Bannerot, R. B. (2002). Synthesizing creative processing in engineering curricula through art. Proceedings of the Annual ASEE Conference, Session 2661, 3129-3140.

35. Pidaparti, R. M. (2004). The art of engineering in capstone design. Proceedings of the Annual ASEE Conference, Session 1725, 591-598.

36. Pines, D., Fuller, J., \& Hahn, T. (2005). Bringing together engineering, architecture, and art students to creatively solve community design issues. Proceedings of the Annual ASEE Conference, Session 3215, 1309-1317.

37. Ragusa, G. (2011). Engineering creativity and propensity for innovative thinking in undergraduate and graduate students. Proceedings of the Annual ASEE Conference.

38. Ralston, P., \& Bays, C. (2010). Refining a critical thinking rubric for engineering. Proceedings of the Annual ASEE Conference.

39. Robertson, B. F., Walther, J., \& Radcliffe, D. F. (2007). Creativity and the use of CAD tools: Lessons for engineering design education from industry. Journal of Mechanical Design, 129(7), 753-760.

40. Salgian, A., Nakra, T. M., Ault, C., \& Wang, Y. (2013). Teaching creativity in computer science. Proceedings of the $44^{\text {th }}$ ACM Technical Symposium, 123-127.

41. Schwarzmeier, J. D., Jacobsen, D. L., Vang, T. T., \& Phillips, A. T. (2007). The musical CPU. Proceedings of the $37^{\text {th }}$ ASEE/IEEE Frontiers in Education (FIE) Conference, S2D07-S2D-12.

42. Shields, E. (2007). Fostering creativity in the Capstone engineering design experience. Proceedings of the Annual ASEE Conference.

43. Sternberg, R. J. (2005). Creativity or creativities? International Journal of Human-Computer Studies, 63, 370-382.

44. Stolk, J., \& Olin, F. W. (2009). Nurturing creative processes and attitudes in introductory materials science. Proceedings of the Annual ASEE Conference.

45. Stouffer, W. B., Russell, J. S., \& Oliva, M. G. (2004). Making the strange familiar: Creativity and the future of engineering education. Proceedings of the Annual ASEE Conference, Session 1615, 9315-9327.

46. Sundaram, H., \& Ingalls, T. (2006). Signal processing for the arts: Reaching out to new audiences. IEEE Signal Processing Magazine, 23(3), 14-18.

47. Torrance, E. P. (1981). Predicting the creativity of elementary school children (1958-80) -- and the teacher who "made a difference." Gifted Child Quarterly, 25(2), 55-62.

48. Traver, C., \& Klein, J. D. (2011). Fostering innovation through integration of engineering education and liberal education. Proceedings of the Annual ASEE Conference.

49. VanDeGrift, T. (2007). Encouraging creativity in introductory computer science programming assignments. Proceedings of the Annual ASEE Conference.

50. Warsame, A., Biney, P. O., \& Morgan, J. O. (1995). Innovations in teaching creative engineering at the freshmen level. Proceedings of the Frontiers in Education (FIE) Conference, 1, 300-303.

51. Wilde, D. (1993). Changes among ASEE creativity workshop participants. Journal of Engineering Education, 82(3), 167-170.

52. Wilkinson, A. J., Miles, R. S., Bateson, A. D., Selke, K. K. W., \& Holley, S. (2002). The 'Mouse Organ' project: A learning approach to promote creativity and innovation. International Journal of Electrical Engineering Education, 39(3), 278-283. 